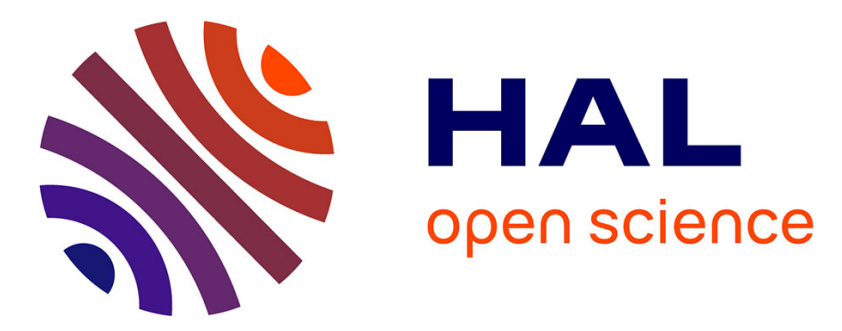

\title{
Digestion of protein of two pollen types in China by the honeybee (Apis mellifera $\mathrm{L}$ )
}

Ying Wang, Lan-Ting Ma, Xiao-Bo Hang, Wei-Ren Yang, Feng Liu, Bao-Hua $\mathrm{Xu}$

\section{- To cite this version:}

Ying Wang, Lan-Ting Ma, Xiao-Bo Hang, Wei-Ren Yang, Feng Liu, et al.. Digestion of protein of two pollen types in China by the honeybee (Apis mellifera L). Apidologie, 2014, 45 (5), pp.590-600. 10.1007/s13592-014-0278-1 . hal-01234760

\section{HAL Id: hal-01234760 https://hal.science/hal-01234760}

Submitted on 27 Nov 2015

HAL is a multi-disciplinary open access archive for the deposit and dissemination of scientific research documents, whether they are published or not. The documents may come from teaching and research institutions in France or abroad, or from public or private research centers.
L'archive ouverte pluridisciplinaire HAL, est destinée au dépôt et à la diffusion de documents scientifiques de niveau recherche, publiés ou non, émanant des établissements d'enseignement et de recherche français ou étrangers, des laboratoires publics ou privés. 


\title{
Digestion of protein of two pollen types in China by the honeybee (Apis mellifera $\mathrm{L}$ )
}

\author{
Ying Wang, Lan-Ting Ma, Xiao-Bo Hang, Wei-Ren YANG, Feng Liu, Bao-Hua Xu, \\ College of Animal Science and Technology, Shandong Agricultural University, Tai' an, Shandong 271018, China
}

Received 2 October 2013 - Revised 14 January 2014 - Accepted 7 February 2014

\begin{abstract}
Different pollens have varying nutritional value for the honeybee. However, the digestion of the protein in the pollen is still not well understood. Here, we investigated this issue using a rectum-testing method. The results indicated that a higher proportion of the protein in camellia pollen is digested compared with the protein in rape pollen. Chemical and histochemical analyses indicated that protein digestion is closely associated with the diet that a worker bee consumes. Our results demonstrate that camellia pollen has a higher nutritive value than rape pollen for honeybees. By influencing midgut development, different bee diets cause discrepancies in digestive and absorptive functions, which are ultimately reflected by differences in protein digestion.
\end{abstract}

Apis mellifera / pollen / protein digestion / mechanism

\section{INTRODUCTION}

As a member of a honeybee community, a worker bee's role changes continually throughout its life. Workers play a nursing role in their first 2 weeks after emerging (Winston 1991); from 3 to 10 days of age, the workers' primary duty is to take care of the brood and to feed the maturing larvae (de Groot 1953). More than $50 \%$ of workers start to consume pollen in the first $12 \mathrm{~h}$ after emerging (Crailsheim et al. 1992). The largest amounts of pollen are consumed at approximately 5 days of age, and pollen consumption begins to diminish from the 8th to the 10th day (Haydak 1970). Foragers seldom eat pollen (Lindauer 1952). Consequently, the nutritive value of pollen is

Corresponding author: B. Xu, bhxu@sdau.edu.cn Manuscript editor: Klaus Hartfelder more important for nursing bees than for foragers, particularly in the first 2 weeks of life.

Studies have been conducted for centuries in the hope of establishing effective scientific methods of evaluating pollen's digestibility and nutritive value for honeybees. Established indexes or methods include the assessment of intestinal proteolytic activity, the development of hypopharyngeal glands and ovaries, nutrient content indexes (e.g., proteins or amino acids), longevity, pollen consumption and digestion, the haemolymph index and histochemical methods (reviewed by de Groot 1953; de Groot 1953; Herbert et al. 1970; Klungness and Peng 1984; Schmidt and Buchmann 1985; Crailsheim et al. 1992; Szolderits and Crailsheim 1993; Pirk et al. 2010; Human et al. 2007). Using these methods, we can reach a good understanding of pollen's nutritive value for honeybees. As yet, there are two used methods for pollen digestion analysis: one is to evaluate the quality of pollen based on the pollen extraction efficiency (i.e., the degree of empty grains after digestion) (Crailsheim et al. 1992; Szolderits and Crailsheim 1993; Human et al. 2007), and the 
other technique is to determine the apparent nitrogen digestibility using faecal collection and a $\mathrm{Cr}_{2} \mathrm{O}_{3}$ marker technique (Schmidt and Buchmann 1985). Together with other methods, pollen extraction efficiency is a good indicator in the evaluation of pollen quality but does not reflect the real protein digestibility of pollen. Thus, the marker technique provides a parameter with which to understand the true value of the nutrients in pollen for honeybees, but it still does not appear to be as satisfactory as total faecal collection based on experimental results (Black 2006).

Midgut is the main site of digestion and absorption (reviewed by Wang 2000). The factor that nutrients can influence the intestinal development has been proved in animals (Jensen and Jørgensen 1994; Zhang et al. 2012) and some species of insect (Zhou et al. 2011). But we still know little about whether the same phenomenon is applicable to honey bees. The peritrophic membrane (PM) is an important structure of the midgut and has many functions (reviewed by Shi et al. 2010). What we are interested in is whether there is any correlation between the protein digestion and the PM characteristic.

Both bees that collected camellia pollen and rape pollen have high crude proteins ( $27.3 \%$ of camellia pollen and $26.8 \%$ of rape pollen in our study) and they are the two most-used pollen sources in China for beekeeping during reproductive periods. However, the digestion of the protein in the pollen of these two species is still not well understood. In the current study, the digestion of the protein in two species of pollen was tested using a new method (i.e., rectum-testing method), and protein consumption, the proteolytic enzyme activity of the midgut, the protein content of the thorax and hypopharyngeal glands, the histology of the PM and the development of the midgut were investigated in honeybees reared on the two pollen types.

\section{MATERIAL AND METHODS}

\subsection{Bees and feeding environment}

Twelve sister colonies (the queens were artificially inseminated) of Apis mellifera L. were used in this study. All of the experiments were conducted in June
2012 at the Shandong Agricultural University in Tai' an, Shandong province, China. Newly emerged workers $(<24 \mathrm{~h})$ were collected from these colonies by hand and maintained in wooden cages $(20 \times 15 \times 10 \mathrm{~cm})$ covered with transparent plastic. All of the cages were placed in an incubator $\left(30{ }^{\circ} \mathrm{C}, 55 \% \mathrm{RH}\right)$. The incubator was maintained at $30{ }^{\circ} \mathrm{C}$ instead of higher temperature because we found the mortality rate of workers was lower at our experimental conditions.

\subsection{Experimental design}

The highest pollen consumption was recorded for 3to 10-day-old workers (Hrassnigg and Crailsheim 1998), and consumption decreased sharply at 12 days of age (Al-Ghamdi et al. 2011). Our previous experiments showed that it takes at least $72 \mathrm{~h}$ for food to reach the rectum after fasting, and defecation was observed if the fast was conducted after the 10th day postemergence under our experimental conditions (data not shown). Thus, we studied three ages (3, 6 and 9 days old). Considering the adverse effect of fasting on test items, we carried out two experiments.

To determine the consumption and digestion of the protein in the two pollen species by bees of different ages, we carried out the first experiment: 1,800 newly emerged workers $(<24 \mathrm{~h}$ old $)$ in 36 cages were randomly and equally divided into three groups $(n=12$ cages in each group, each cage contained 50 workers). One group was fed camellia pollen diet (CPD) and the second group was fed rape pollen diet (RPD). The third group was not fed any pollen diets (Control).

To find out the possible mechanisms and avoid the adverse effects of the fasting, we carried out the second experiment: Six hundred newly emerged workers $(<24 \mathrm{~h}$ old $)$ in 12 cages were randomly taken from these colonies and equally divided into three groups (CPD, RPD and control), each group had four cages. Each cage contained 50 workers. The treatment's impact on the proteolytic enzyme activity of the midgut, the protein content of the thorax and the development of the hypopharyngeal glands and midgut were investigated.

\subsection{Pollen and diets preparation}

Camellia pollen and rape pollen were obtained from the Jiangxi and Hubei provinces, respectively. 
The pollen was collected from honeybee (A. mellifera L.) colonies in 2011 using pollen traps. These two pollen plants are cultivated on large areas of land in the collection regions in China, and can nearly maintain purity of other pollen. So the species of the pollen samples used in this study were well controlled. To keep bees from spreading the diets all over the cage and benefit bees to ingestion. The pollen was powdered and sifted before being mixed with $56 \%$ sucrose in water at a $2: 1$ to $2: 1.5$ weight ratio. The camellia pollen diet (CPD) and rape pollen diet (RPD) were stored at $-20{ }^{\circ} \mathrm{C}$ until use.

Water and acacia (Robinia pseudoacacia) honey were provided to the treated bees ad libitum. No protein content was detected in the provided acacia honey or sugar water, so the effect of acacia honey or sugar water on protein consumption was ignored. Water and acacia honey were provided first to ensure the survival of the workers, and the pollen diets were supplied $3 \mathrm{~h}$ later. The diets, water and honey were checked twice per day.

\subsection{Calculation of protein consumption and digestion}

The pollen diets were rolled up in a ball, weighed (DW, to the nearest $0.1 \mathrm{mg}$, dry-weight) and placed on glass microscope slides before being deposited in the cages. On the third, sixth and ninth days after the bees emerged, four cages were randomly selected from each group and marked, and the remainder of the pollen diet was removed from the cages. A 72-h fast was then conducted. Water and acacia honey were still provided during fasting. At the end of the fast, the workers in each cage were rapidly euthanised, and the faeces-containing rectums were carefully isolated on glass slides using tweezers.

The proportion of protein in the pollen diets $(w$, in percent), the diet remaining in the cages (RCP, in milligramme) and the rectums (PR, in milligramme) of the three groups were estimated using the Kjeldahl method as shown by Hoegger (1998) to determine total nitrogen and multiplying that value by a factor of 6.25 to calculate the crude protein content. We chose the rectum protein of fasted 6th, 9th and 12th days CG bees but not the fasted 3rd, 6th and 9th days as blanks because the increasing endogenous protein in the rectum during the fast period $(72 \mathrm{~h}$, about
3 days) must be taken into account. We defined this three rectum protein contents as blank protein (BP, in milligramme per bee) at each corresponding stage. Protein consumption ( $\mathrm{PC}$, in milligramme) and protein digestion were then calculated (see 2.8).

\subsection{Proteolytic enzyme activity in the midgut}

On the third, sixth and ninth days, 15 workers from each cage were randomly selected and rapidly euthanised. The midguts were separated, and the Malpighian tubes were carefully removed. Ten midguts were used for proteolytic enzyme activity testing, four of the fiveremaining midguts were used for midgut development research, and the remaining heads and thoraxes were stored at $-40{ }^{\circ} \mathrm{C}$ until further testing. The midguts were homogenised in Tris-HCl buffer (1,000 $\mu \mathrm{L} ; \mathrm{pH}$ 7.9), and centrifuged at $10,621 \times \mathrm{g}$ for $5 \mathrm{~min}$. The supernatants were used to determine the proteolytic enzyme activity with the Folin phenol reagent using the method of described by Lowry et al. (1951). The absorbance was measured at $630 \mathrm{~nm}$ using a Bio-Tek ELx808 absorbance microplate reader (Bio-Tek Co., Winooski, VT., USA). The midgut proteolytic enzyme activity was calculated as the average optical density (OD) value of the sample minus the corresponding sample's average blank OD, and the enzyme activity was expressed in terms of $\mathrm{OD}_{630}$.

\subsection{Protein content of the thorax and hypopharyngeal glands}

For each cage of every treatment group, 13 thoraxes were randomly selected from the abovementioned frozen samples (see Section 2.5), and the crude protein in the thorax (in milligramme per bee for each treatment) was determined using the Kjeldahl method as shown by Hoegger (1998).

The hypopharyngeal glands of five workers from each cage were removed, placed in a centrifuge tube and stored at $-40{ }^{\circ} \mathrm{C}$ until analysis. The samples were thawed, homogenised and gently sonicated with cold sodium chloride solution $\left(0.7 \%\right.$, approximately $\left.4{ }^{\circ} \mathrm{C}\right)$ at a ratio of $1: 99$. The mixture was then centrifuged at $10,000 \mathrm{rpm}$ at $4{ }^{\circ} \mathrm{C}$ for $5 \mathrm{~min}$. The protein content of the supernatant was determined using a BCA Protein Assay Kit (Micro Assay) A045-1 (Beijing Dingguo 
Changsheng Biotechnology Co., Ltd, Beijing, China). Three $10 \mu$ l aliquots of each sample supernatant were added to individual microplate wells, after which $200 \mu \mathrm{l}$ dilute BCA reagent (50: 1, Reagent A: B) was added and mixed well using a pipette. The microplates were then incubated at $37^{\circ} \mathrm{C}$ for $30 \mathrm{~min}$. The absorbance was measured at $570 \mathrm{~nm}$ using a Bio-Tek microplate reader at room temperature, and the hypopharyngeal glands' protein content ( $n=5$ workers) was expressed in terms of $\mathrm{OD}_{570}$.

\subsection{Midgut development}

The midguts of 16 workers from each group (four from each cage) collected on the third, sixth and ninth days were used to study midgut development. The midguts were separated and rapidly transferred to a $10 \%$ buffered neutral formaldehyde solution (pH 7.2). The samples were prepared for optical microscopy as described in Yu and Chiou (1997). All of the midgut samples were gradually dehydrated and then embedded in paraffin, sectioned at $5 \mu \mathrm{m}$, stained with haematoxylin and eosin ( $\mathrm{H} \& \mathrm{E})$. The paraffin sections were observed and photographed using a microscope, and the intestinal histology indexes were measured from these pictures using a measuring tool with Adobe Photoshop CS2 9.0 software. The midgut and PM thickness values were the average of the 16 workers' measurements, and the midgut thickness was the length measured from the bottom of the crypt to the peritoneal membrane.

\subsection{Statistical analysis}

We calculated the protein consumption $(\mathrm{PC}$, in milligrammer) and protein digestion of pollen diet using the following formulae:

Protein consumption was calculated as:

$\mathrm{PC}=\frac{W \times \mathrm{DW} \times 1,000-\mathrm{RCP}}{N}$

Where $w$ (in percent) is the proportion of protein in the pollen diets; DW (in gramme) is the total diet weight that given to each caged bees; RCP (in milligrammer) is the protein content of the remaining diets in the corresponding cage; and $N$ is the number of bees in the corresponding cage.
We calculated the protein digestion of these two pollen diets as follows:

Protien digestion $=\frac{\mathrm{PC} \times N-\mathrm{PR}+N \times \mathrm{BP}}{\mathrm{PC} \times N} \times 100 \%$

Where PR (in milligramme) is the protein content in the rectums of the whole caged bees, and BP (in milligramme per bee) is the endogenous protein content in the rectum of the corresponding aged control bee.

The data presented were interpreted with one-way ANOVA analyses using SAS (SAS 9.1, SAS Institute 2003). The values are reported throughout the study as the means $\pm \mathrm{SE}$. To compare the data, Duncan's multiple-range test was used, and differences were deemed significant at $P<0.05$.

\section{RESULTS}

\subsection{Protein consumption}

Pollen consumption was low on the first 3 days and increased with age. There was no significant difference in protein consumption between the camellia pollen and the rape pollen at each age (Figure 1).

\subsection{Protein digestion}

The rectum protein content of the control is about $0.86,1.01$ and $1.29 \mathrm{mg}$ for each worker aged 6,9 and 12 days old. So this parameter

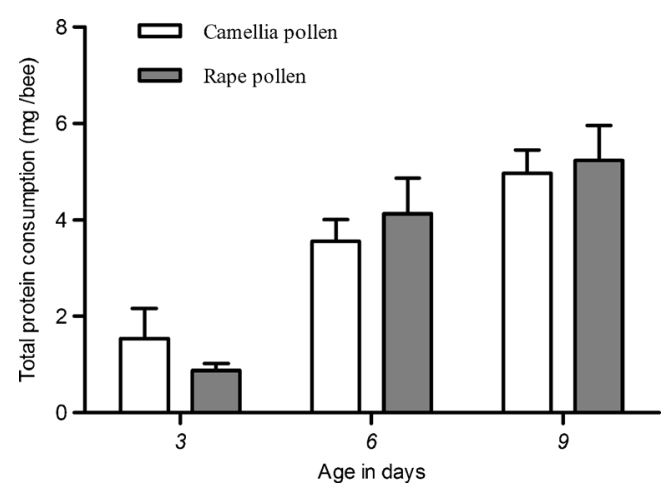

Figure 1. Total protein consumption by caged bees. The amounts of protein consumed by the CPD and RPD groups were similar at 3, 6 and 9 days. The data are reported as the mean $+\mathrm{SE}$. 
should be taken into consideration. We did observe significant differences in protein digestion by the workers for these two pollen types. Protein digestion by the bees was significantly higher for the CPD than for the RPD in all three age groups (third day: $F_{1,6}=10.36, P<0.05$; sixth day: $F_{1,6}=10.32, P<0.05$; and ninth day: $F_{1,6}=4.41, P<0.05$ ) (Figure 2). The temporal trend of protein digestion was similar between the CPD and the RPD, with the most complete digestion of the protein in both pollen types occurring on the third day $(78.90 \pm 2.79 \%$ of the CPD and $67.48 \pm 2.19 \%$ of the RPD), after which protein digestion gradually declined (sixth day, $73.25 \pm 2.55 \%$; and ninth day, $72.50 \pm 1.50 \%$ of the CPD and sixth day: $64.07 \pm 1.28 \%$; and ninth day: $63.05 \pm 1.92 \%$ of the RPD), but we did not observe a significant difference for the CPD $\left(F_{2,9}=2.18\right.$, $P>0.05)$ or the RPD $\left(F_{2,9}=1.59, P>0.05\right)$ over the entire experimental period.

\subsection{Proteolytic enzyme activity in the midgut}

To determine whether the difference in protein digestion is caused by the levels of proteolytic enzymes in the midgut, we exam-

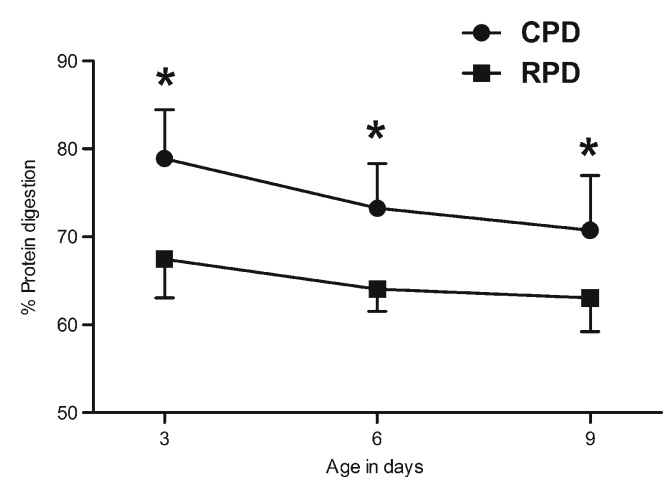

Figure 2. Protein digestion by caged CPD and RPD bees. The CPD group exhibited significantly higher protein digestion than the RPD group at each age, but no significant difference was found between the ages within the CPD or RPD group. The data are reported as the mean+SE $(C P D)$, and the mean-SE $(R P D)$. Differences were deemed statistically significant at $P$ $<0.05$ and are represented by asterisk. ined the workers' midgut proteolytic enzyme activity on their third, sixth and ninth days. Proteolytic enzyme activity exhibited an agedependent trend, and the highest levels of proteolytic activity were measured in the day 6 group (Table I). Significant differences were observed between the pollen diet groups and CG for each of the three ages (third day: $F_{2,9}=$ 19.34, $P<0.05$; sixth day: $F_{2,9}=9.92, P<0.05$; and ninth day: $\left.F_{2,9}=450.16, P<0.05\right)$. The $C G$ had significantly lower proteolytic enzyme activity at each age than the CPD and RPD groups, and a steep decrease in proteolytic activity was observed in 9-day-old CG bees, whose proteolytic enzyme activity was very low by the ninth day. There was no significant difference between the CPD and RPD for the 3and 9-day-old bees, and no significant differences were found between the CPD and the RPD groups at the same age.

\subsection{PM thickness}

To determine the mechanisms responsible for the different digestion of the protein in the two pollen species, we investigated the development of the midgut on the third, sixth and ninth day. We found that the PM thickness is associated with protein digestion and also varies according to diet and age (Table I). The PM of the bees in the CPD group was significantly thinner than the PM of the bees in the RPD and CG groups. In particular, the PM of the CPD bees was threefold thinner in a 3day-old, twofold thinner in a 6-day-old and 1.5fold thinner in a 9-day-old compared with the RPD bees of the same age.

\subsection{Midgut development}

The midgut wall thickness of the three groups is represented in Table I. The midgut wall thickness was closely associated with protein digestion and diet. Caged bees in the CPD group had a significantly thicker midgut wall than RPD and CG bees at the same age, and a significance difference was found between the RPD and the CG bees on the sixth and ninth days. 
Table I. Effects of the CPD and RPD groups and CG on midgut proteolytic enzyme activities, PM thickness, midgut thickness, the protein content of the thorax and hypopharyngeal gland of caged bees aged 3,6 and 9 days old

\begin{tabular}{|c|c|c|c|c|}
\hline & \multirow[t]{2}{*}{ Ages, days } & \multicolumn{3}{|l|}{ Treatment } \\
\hline & & CPD & RPD & $\mathrm{CG}$ \\
\hline \multirow[t]{3}{*}{ Proteolytic enzyme activitys $\left(\mathrm{OD}_{630}\right)$} & 3 & $0.25 \pm 0.022 \mathrm{a}$ & $0.25 \pm 0.025 \mathrm{a}$ & $0.16 \pm 0.022 \mathrm{~b}$ \\
\hline & 6 & $0.43 \pm 0.040 \mathrm{a}$ & $0.37 \pm 0.052 \mathrm{a}$ & $0.29 \pm 0.03 \mathrm{~b}$ \\
\hline & 9 & $0.28 \pm 0.013 \mathrm{a}$ & $0.27 \pm 0.019 \mathrm{a}$ & $0.023 \pm 0 . \% \mathrm{~b}$ \\
\hline \multirow[t]{3}{*}{ PM thickness $(\mu \mathrm{m})$} & 3 & $27.17 \pm 3.64 \mathrm{c}$ & $84.03 \pm 5.88 \mathrm{a}$ & $67.23 \pm 5.89 \mathrm{~b}$ \\
\hline & 6 & $58.82 \pm 8.96 \mathrm{~b}$ & $112.04 \pm 10.64 \mathrm{a}$ & $98.04 \pm 9.52 \mathrm{a}$ \\
\hline & 9 & $86.83 \pm 10.08 \mathrm{~b}$ & $126.05 \pm 8.96 \mathrm{a}$ & $75.63 \pm 8.12 b$ \\
\hline \multirow[t]{3}{*}{ Midgut thickness $(\mu \mathrm{m})$} & 3 & $21.29 \pm 1.20 \mathrm{a}$ & $15.97 \pm 0.78 \mathrm{~b}$ & $16.53 \pm 0.78 \mathrm{~b}$ \\
\hline & 6 & $26.33 \pm 1.65 \mathrm{a}$ & $16.25 \pm 0.67 \mathrm{~b}$ & $10.64 \pm 0.64 \mathrm{c}$ \\
\hline & 9 & $20.17 \pm 0.95 \mathrm{a}$ & $15.97 \pm 1.06 \mathrm{~b}$ & $10.36 \pm 0.76 \mathrm{c}$ \\
\hline \multirow[t]{3}{*}{ Thorax protein content (mg/bee) } & 3 & $9.59 \pm 0.67 \mathrm{a}$ & $9.65 \pm 0.25 \mathrm{a}$ & $8.56 \pm 0.069 \mathrm{~b}$ \\
\hline & 6 & $10.77 \pm 0.30 \mathrm{a}$ & $10.69 \pm 0.80 \mathrm{a}$ & $8.90 \pm 0.21 \mathrm{~b}$ \\
\hline & 9 & $11.42 \pm 0.29 \mathrm{a}$ & $11.30 \pm 0.66 \mathrm{a}$ & $9.33 \pm 0.07 \mathrm{~b}$ \\
\hline \multirow{3}{*}{$\begin{array}{l}\text { Hypopharyngeal gland protein } \\
\text { content }\left(\mathrm{OD}_{570}\right)\end{array}$} & 3 & $0.29 \pm 0.02 \mathrm{a}$ & $00.29 \pm 0.008 \mathrm{a}$ & $0.25 \pm 0.02 \mathrm{~b}$ \\
\hline & 6 & $0.29 \pm 0.01 \mathrm{a}$ & $0.27 \pm 0.01 \mathrm{a}$ & $0.21 \pm 0.02 \mathrm{~b}$ \\
\hline & 9 & $0.28 \pm 0.02 \mathrm{a}$ & $0.26 \pm 0.014 \mathrm{a}$ & $0.2 \pm 0.03 \mathrm{~b}$ \\
\hline
\end{tabular}

The data are reported as the mean $\pm \mathrm{SE}$

Means within a row with different letters $(a, b)$ differ significantly $P<0.05)$

The histological structure of the midgut of the workers at the three studied ages was also assessed through morphological observations (Figure 3a-i). Significant differences in the structure of the midgut in the CPD, RPD and CG bees are easily observable in the micrographs (Figure $3 \mathrm{a}-\mathrm{c}$ and $\mathrm{d}-\mathrm{f}$, respectively), and the shape of the midgut crypts varied between the three groups. The crypts of the CPD bees were more closely spaced and had a smaller inside diameter than the crypts of the RPD and CG bees.

\subsection{Protein content of the thorax and hypopharyngeal glands}

To determine whether pollen protein digestion has an effect on the development of the thorax and hypopharyngeal glands, we tested the protein content of these organs.
There was an obvious trend of the protein content of the thorax increasing with age (Table I). The CG bees had significantly lower thorax protein content than the CPD and RPD bees at each age, but no significance difference was found between the CPD and the RPD bees. The hypopharyngeal glands' protein content was influenced by diet (Table I). The CG had significantly lower hypopharyngeal-gland protein content at 3 days $\left(F_{2,9}=6.51, P<0.05\right)$, 6 days $\left(F_{2,9}=38.96, P<0.05\right)$ and 9 days $\left(F_{2}\right.$, $9=14.97, P<0.05)$ compared with the CPD and RPD groups, but there was no significant difference between the CPD and the RPD groups in any of the three age groups. Additionally, the variation in the hypopharyngeal-gland protein content over time differed between the three groups. The bees in the CPD treatment group maintained a similar hypopharyngeal-gland protein content over the entire experimental period $\left(F_{2,9}=0.75, P>\right.$ 


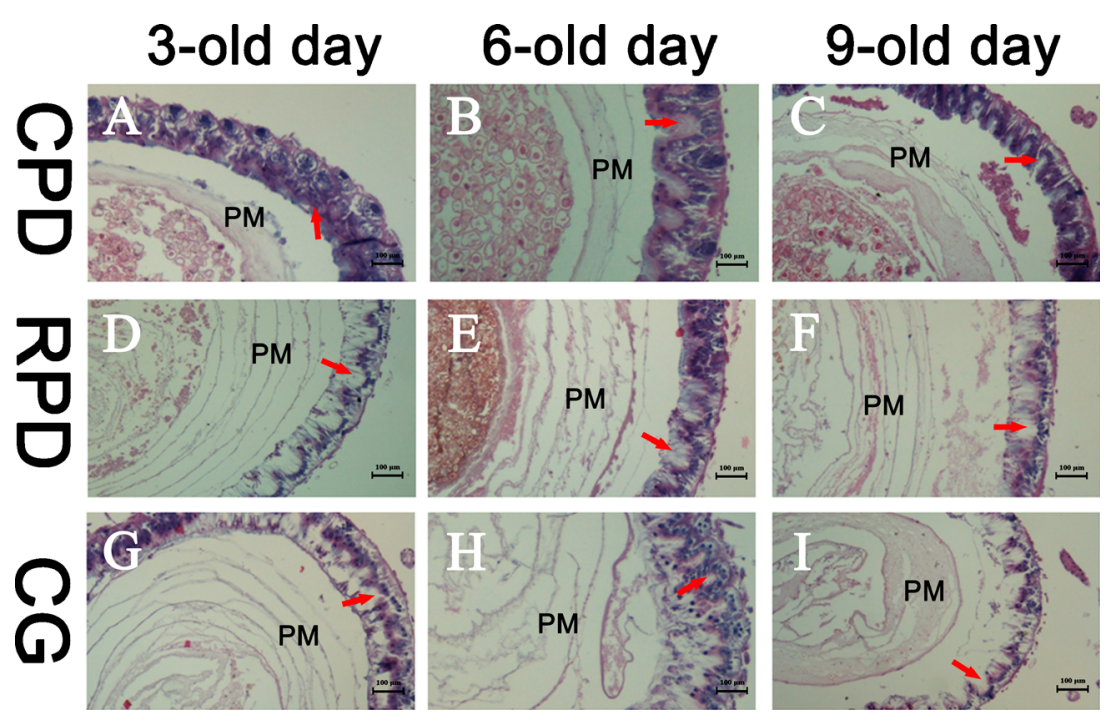

Figure 3. Cross-section of the midgut of workers aged 3, 6 and 9 days old. a-c, $\mathbf{d}-\mathbf{f}$ and $\mathbf{g}-\mathbf{i}$ correspond to the CPD, RPD and CG, respectively. PM peritrophic membrane. The red arrows indicate the crypts $(\mathrm{H} \& \mathrm{E}, \times 10)$.

0.05), whereas significant differences were found in the RPD and CG bees (RPD: $F_{2,9}=$ 8.89, $P<0.05$; and CG: $\left.F_{2,9}=8.62, P<0.05\right)$, with the protein content progressively decreasing with increasing age.

\section{DISCUSSION}

Factors that affect protein digestion have been well characterised in animal nutrition (McDonald 2002). Protein digestion and absorption are influenced by the type of animal (e.g., species, age), diet (e.g., nutrient content and proportions), environment and feeding technology factors. The nutrition and digestibility of pollen for honey bee or animals is also different (reviewed by Roulston and Cane 2000; Roulston et al 2000), and this may be closely related with pollen types, sizes and the characteristic of pollen wall. Recent studies have confirmed that the consumption of pollen and pollen substitute can be influenced by protein levels (Pernal and Currie 2000; Wang et al. 2011; Li et al. 2012). The similar protein consumption may be also related to the similar protein content of the two pollen and prepared pollen diets ( $15.6 \%$ of the CPD, and $14.2 \%$ of the RPD). It also showed that the difference in protein diges- tion was not caused by protein consumption but may be by the nature of the two pollen types and their effects on the workers.

Proteolytic enzyme activity is age-dependent (Grogan and Hunt 1980) and closely related to the protein content of the midgut (Moritz and Crailsheim 1987). Our results were in agreement with these previous studies. Li et al. (2012) reported that proteolytic enzyme activity was influenced by protein levels and by the species of the food in natural hives. It was interesting that the protein digestion of CPD or RPD of the three stages was similar although the proteolytic activity was highest in 6-day-old bees. The changed proteolytic activity levels indicating that it might be influenced by the midgut development. It is interesting that the proteolytic activity of CPD and RPD was lower in 3- and 9-day-old bees, but the protein digestion was similar. This result reflects that protein digestion was not related to proteolytic enzyme activity in this study. The similar proteolytic enzyme activity may mean the same digestion ability, so the digestion difference maight be caused by the different of midgut absorption between these two treatments. The significant differences in proteolytic enzyme activity between the pollen diet groups and the CG indicated that the differences 
were caused not by the consumption of honey or water but by the pollen diets. It indicates that the proteolytic enzyme activity may remain at low levels in low-protein conditions.

Interestingly, the proteolytic enzyme activity of the CG increased at first but subsequently sharply decreased. We believe that this pattern was caused by one of two possible mechanisms. For the first 6 days after emerging, young bees require nutrients to meet their growth and developmental needs. They had no choice but to consume honey and water. Thus, a large quantity of honey was consumed, which may have played a role as a pseudo-diet physical stimulus for the mechanoreceptors located on the intestinal wall, activating secretory activity. Secretion could not be sustained, however, due to a lack of chemical signals, and particularly the protein digestion products. Thus, the proteolytic enzyme activity became very low by the ninth day. Furthermore, autophagy is used as a measure to maintain cell homeostasis when body is suffering from starvation (Tettamanti et al. 2007), which typically causes cell death (Tettamanti et al. 2006). In the CG bees, the poor structure of the midgut may also be due to autophagy of the epithelial cells. As previous studies have described (Tettamanti et al. 2007), by consuming or recycling intracellular nutrients in the early phase of starvation, which may continue for several days, epithelial cells can maintain certain normal functions (e.g., secretion). Autophagy may also explain why the proteolytic enzyme activity increased for the first 6 days; cell deaths may have provided nutrients for the remaining cells. The development of regenerative cells are also influenced by malnutrition. The midgut structure was destroyed as a result of the apoptotic rate becoming faster than the regeneration rate as time passed, and the secretory activity of the epithelial cells was nearly deactivated, leading to a very low level of proteolytic enzyme activity in the 9-day-old CG bees.

Higher protein digestion means more amino acids absorption, so the protein content of the CPD bees was greater than in the RPD ones. We can also know that the abdominal protein content of CPD bees was higher than in RPD bees due to the similar protein contents in the thorax and hypopharyngeal glands. There is a direct correlation between the activity of the hypopharyngeal glands and the protein content of the glands (Rosca and Rusu 1972). The development of the hypopharyngeal glands heavily depends on the protein supply (Rosca and Rusu 1972). Thus the CPD bees may be better able to maintain the activity of the hypopharyngeal gland and sustain a longer nursing period than the RPD ones. Foragers seldom eat pollen (Lindauer 1952). For the CG bees, the protein content of the hypopharyngeal glands decreased significantly after the third day, indicating that hypopharyngeal gland activity will decreases if the bees are subjected to prolonged protein deficiency. This finding may be partly explain why the hypopharyngeal gland activity of foragers is lower than that of nursing bees. The similar protein content of the 6 - and 9-day-old CG bees suggests that a rearrangement of protein in or transfer of protein from the abdomen or thorax may be activated during protein deficiency, which would ensure the basic functioning of the hypopharyngeal glands and slow the reduction in activity.

Another interesting finding is that the protein content of the thorax in CG bees still increased with age, even under no-protein conditions, indicating that a rearrangement or transfer of the body's protein was occurring. Combined with the decreasing protein content of the hypopharyngeal glands, the additional protein may be primarily transferred from the abdomen and partly from the royal jelly secreted by the hypopharyngeal glands through trophallaxis. The variation in protein content of $\mathrm{CG}$ bees indicated that the protein content changes based on individual factors and nutritional conditions.

The PM of the honeybee is produced by secretory cells located in the midgut epithelium (Peters 1992). So camellia pollen may be better able to slow the refresh rate of secretory cells. Additionally, our study confirmed that protein digestion is closely associated with the development of the midgut and with PM thickness. The CPD bees, which digested a higher amount of protein, had a thicker mid-intestine wall, 
thinner PM thickness and better-developed crypts than the other bees.

The columnar cells of the midgut play an important role in digestion and ingestion (Casartelli et al. 2001). The histochemical analyses indicated that midgut development was also affected by diet, which suggests that protein digestion was influenced by differences in the absorptive capacity of the midgut and in the pollens themselves. Protein digestion varies with different diets. Diet effects were the primary factor that influenced midgut development. By influencing midgut development, the diets cause discrepancies in digestive and absorptive functions, which is ultimately reflected by differences in protein digestion. The digestion of the protein in the CPD and RPD displayed a slightly declining trend, but the statistical results indicated that neither pollen type had significantly different levels of protein digestion between the three ages. Protein digestion may decrease in foragers, but due to our experimental constraints, we were limited to the finding that the digestion of the protein during the bees' nursing period.

Our study also indicated that when we need to evaluate the nutritive value of pollen or a pollen substitute for bees, an examination of proteolytic enzyme levels and the development of body or organ tissues may not be sufficient. Thus, macroscopic- and microscopic-level studies should be combined. This rectum-testing method is so powerful that it also applies especially to predicating nutrients digestibility and evaluating feed (as in pollen or pollen substitutes) nutritive values for honey bees. We believe that our research will contribute greatly to improve the knowledge of honeybee nutrition and the evaluating pollen's digestibility and nutritive value for honey bees.

The spore types, sizes and the characteristic of exine may also cause the pollen digestion difference (Klungness and Peng 1984; Roulston et al. 2000; reviewed by Roulston and Cane 2000). The difference in the completeness of protein digestion might also be influenced by the difference in morphology and characteristic of the spore between the two pollen grains. We used Kjeldahl method to test the protein digestion, but there still some evidences that the amino acid and polypeptide might be a better index when compared to crude protein (Nicolson and Human 2013; Vanderplanck et al. 2013). Thus much more work needs to be done to determine which index will appropriate. Furthermore, our study was conducted outside of the hive and under queenless conditions. Future studies are required to investigate the digestion of pollen protein in bees and the nutritive value of pollen for honeybees under nature or queenright conditions, and different collection or storage conditions should also be considered.

\section{ACKNOWLEDGEMENTS}

We are grateful to Li, X. Y., Liu, Z. H., Sun, R. J., Zhang, G. L. and Zhang, G. J. for assistance. This research was financially supported by the earmarked fund for the China Agriculture Research System (CARS-45) and the Special Fund for Agro-Scientific Research in the Public Interest (no. 200903006).

Digestion de la protéine de deux types de pollen par les abeilles (Apis mellifera) en Chine

Valeur nutritionnelle / pollen / camélia / colza / mécanismes de la digestion

Verdauung der Proteine von zwei Pollentypen aus China durch die Honigbiene (Apis mellifera)

\section{Apis mellifera / Pollen / Proteinverdau / Mechanismus}

\section{REFERENCES}

Al-Ghamdi, A.A., Al-Khaibari, A.M., Omar, M.O. (2011) Consumption rate of some proteinic diets affecting hypopharyngeal glands development in honeybee workers. Saudi J. Biol. Sci. 18(1), 73-77

Black, J. (2006) Honeybee nutrition: review of research and practices. Rural Industries Research and Development Corporation, Canberra

Casartelli, M., Leonardi, M., Fiandra, L., Parenti, P., Giordana, B. (2001) Multiple transport pathways for dibasic amino acids in the larval midgut of the silkworm Bombyx mori. Insect Biochem. Mol. Biol. 31(6), 621-632 
Crailsheim, K., Schneider, L., Hrassnigg, N., Bühlmann, G., Brosch, U., Gmeinbauer, R., Schöffmann, B. (1992) Pollen consumption and utilization in worker honeybees (Apis mellifera carnica): dependence on individual age and function. J. Insect Physiol. 38(6), 409-419

de Groot, A.P. (1953) Protein and amino acid requirements of the honeybee (Apis mellifica L.). Physiol. Comp. Oecol. 3, 197-285

Grogan, D.E., Hunt, J.H. (1980) Age correlated changes in midgut protease activity of the honeybee Apis mellifera (Hymenoptera, Apidae). Experientia 36(12), 1347-1348

Haydak, M.H. (1970) Honey bee nutrition. Annu. Rev. Entomol. 15(1), 143-156

Herbert, E., Bickley, W., Shimanuki, H. (1970) The brood-rearing capability of caged honey bees fed dandelion and mixed pollen diets. J. Econ. Entomol. 63(1), 215-218

Hoegger, R. (1998) Training papers nitrogen determination according to Kjeldahl. Büchi Labortechnik AG. Flawil 1, 18

Hrassnigg, N., Crailsheim, K. (1998) The influence of brood on the pollen consumption of worker bees (Apis mellifera L.). J. Insect Physiol 44(5), 393-404

Human, H., Nicolson, S., Strauss, K., Pirk, C., Dietemann, V. (2007) Influence of pollen quality on ovarian development in honeybee workers (Apis mellifera scutellata). J. Insect Physiol. 53(7), 649-655

Jensen, B.B., Jørgensen, H. (1994) Effect of dietary fiber on microbial activity and microbial gas production in various regions of the gastrointestinal tract of pigs. Appl. environ. Microbiol. 60(6), 1897-1904

Klungness, L.M., Peng, Y.S. (1984) A histochemical study of pollen digestion in the alimentary canal of honeybees (Apis mellifera L.). J. Insect Physiol 30(7), 511-521

Li, C., Xu, B., Wang, Y., Feng, Q., Yang, W. (2012) Effects of dietary crude protein levels on development, antioxidant status, and total midgut protease activity of honey bee (Apis mellifera ligustica). Apidologie 43(5), 576-586

Lindauer, M. (1952) Ein beitrag zur frage der arbeitsteilung im bienenstaat. Zeitschrift für vergleichende Physiologie 34(4), 299-345

Lowry, O.H., Rosebrough, N.J., Farr, A.L., Randall, R.J. (1951) Protein measurement with the Folin phenol reagent. J. Biol. Chem. 193, 365-275

McDonald P. (2002) Animal nutrition. Pearson Education India.

Moritz, B., Crailsheim, K. (1987) Physiology of protein digestion in the midgut of the honeybee ( Apis mellifera L.). J. Insect Physiol 33(12), 923-931

Nicolson, S.W., Human, H. (2013) Chemical composition of the 'low quality' pollen of sunflower (Helianthus annuus, Asteraceae). Apidologie 44, 144-152
Pirk, C.W.W., Boodhoo, C., Human, H., Nicolson, S.W. (2010) The importance of protein type and protein to carbohydrate ratio for survival and ovarian activation of caged honeybees (Apis mellifera scutellata). Apidologie 41, 62-72

Pernal, S.F., Currie, R.W. (2000) Pollen quality of fresh and 1-year-old single pollen diets for worker honey bees (Apis mellifera L.). Apidologie 31(3), 387-410

Peters, W. (1992) Peritrophic membranes (Vol. 30). Springer.

Roulston, T.H., Cane, J.H. (2000) Pollen nutritional content and digestibility for animals. Plant Syst. Evol. 222, 187-209

Roulston, T.H., Cane, J.H., Buchmann, S.L. (2000) What governs protein content of pollen: pollinator preferences, pollen-pistil interactions, or phylogeny? Ecol. Monogr. 70(4), 617-643

Rosca O. C., Rusu F. C. (1972) Effect of protein supplements on the developments and secretory activity of the hypopharyngeal glands in the honeybees. Lucr. Stiint. Inst. Agron H.: 93-98.

SAS Institute. (2003) SAS/STAT User's Guide: Version 9.1th edn.

Schmidt, J.O., Buchmann, S.L. (1985) Pollen digestion and nitrogen utilization by Apis mellifera L. (Hymenoptera: Apidae). Comp. Biochem. Physiol. Part A: Physiology 82(3), 499-503

Shi, J.R., Liu, B., Ma, Y., Shen, Y.H. (2010) Advances in research of peritrophic membrane in insects. Newsl. Seric. Sci. 30(3), 7-13

Szolderits, M.J., Crailsheim, K. (1993) A comparison of pollen consumption and digestion in honeybee (Apis mellifera carnica) drones and workers. J. Insect Physiol. 39(10), 877-881

Tettamanti, G., Grimaldi, A., Casartelli, M., Ambrosetti, E., Ponti, B., Congiu, T., Ferrarese, R., Rivas-Pena, M.L., Pennacchio, F., Eguileor, M. (2007) Programmed cell death and stem cell differentiation are responsible for midgut replacement in Heliothis virescens during prepupal instar. Cell Tissue Res. 330(2), 345-359

Tettamanti, G., Malagoli, D., Marchesini, E., Congiu, T., de Eguileor, M., Ottaviani, E. (2006) Oligomycin A induces autophagy in the IPLB-LdFB insect cell line. Cell Tissue Res. 326(1), 179-186

Vanderplanck, M., Leroy, B., Wathelet, B., Wattiez, R., Michez, D. (2013) Standardized protocol to evaluate pollen polypeptides as bee food source. Apidologie . doi:10.1007/s13592-013-0239-0

Wang, G.Y., Wu, Z.F., Yang, W.R., Xu, B.H. (2011) Effects of dietary protein levels on hypopharyngeal gland development and royal jelly production of Apis mellifera L. Chin. J. Anim. Nutr. 23, 1147-1152

Wang, X.R. (2000) The progress of study on the physiology and histopatology of insect midgut. J. Zhongkai Agrotechnical College 13(1), 58-68 
Winston M. L. (1991) The biology of the honey bee. Harvard University Press.

Yu, B., Chiou, P.W.S. (1997) The morphological changes of intestinal mucosa in growing rabbits. Lab. Anim. 31(3), 254-263

Zhang, T., Gui, H., Yue, Z.G., Yang, Y., Gao, X.H., Yang, F.H., Xing, X.M. (2012) Effects of dietary protein level on gastrointestinal digestive enzyme activity and jejunal morphology in minks during winter hair period. Chin. J. Anim. Nutr. 24(2), 376-382

Zhou, Q., Xiong, Z.Y., Ou, X.M. (2011) Effects of sterols from Xanthium sibiricum (Compositae) on feeding, enzyme activities in the hemolymph and midgut, and midgut tissues of Pieris rapae (Lepidoptera: Pieridae) larvae. Acta Entomol. Sin. 54(9), 1034-1041 